\title{
Peran Keluarga untuk Mencegah Adverse Events dan Meningkatkan Keselamatan Pasien di Rumah Sakit
}

\author{
Yosepine Megawati \\ yosepinemegawati28@gmail.com
}

\section{LATAR BELAKANG}

Keluarga merupakan unit paling dekat dengan pasien, dan merupakan perawat utama bagi pasien. Keluarga berperan dalam menentukan cara atau perawatan yang diperlukan pasien di rumah sakit. Keberhasilan perawat di rumah sakit akan sia-sia jika tidak diteruskan di rumah yang kemudian mengakibatkan pasien harus dirawat kembali (kambuh). Peran serta keluarga sejak awal perawatan di rumah sakit akan meningkatkan kemampuan keluarga merawat pasien di rumah sehingga memungkinkan pasien tidak kambuh atau dapat dicegah. Keluarga merupakan bagian dari tim pengobatan dan perawatan. Apalagi di Indonesia dengan kultur sosialnya tinggi ditambah keterbatasan jumlah perawat di rumah sakit sehingga tugas merawat orang sakit yang dirawat di rumah sakit umumnya dilakukan oleh keluarga yang menjaga. Para anggota keluarga menunggui secara bergantian, bahkan sering menjaga bersama-sama. Sementara perawat di rumah sakit yang seharusnya merawat orang sakit juga harus melakukan tugas-tugas yang lain di bangsal perawatan. Maka, peran keluarga penting untuk memantau kebutuhan pasien dari laporan perawat atau jika perlu malakukan komunikasi langsung.

Adverse Event atau Kejadian Tidak Diharapkan (KTD) merupakan suatu kejadian yang mengakibatkan cedera yang tidak diharapkan pada pasien karena suatu tindakan (commission) atau tidak mengambil tindakan yang seharusnya diambil (omission), dan bukan karena "underlying disease" atau kondisi pasien. Kesalahan tersebut bisa terjadi dalam tahap diagnostic seperti kesalahan atau keterlambatan diagnose, tidak menerapkan pemeriksaan yang sesuai, menggunakan cara pemeriksaan yang sudah tidak dipakai atau tidak bertindak atas hasil pemeriksaan atau observasi; tahap pengobatan seperti kesalahan pada prosedur pengobatan, pelaksanaan terapi, metode penggunaan obat, dan keterlambatan merespon hasil pemeriksaan asuhan yang tidak layak; tahap preventive seperti tidak memberikan terapi provilaktik serta monitor dan follow up yang tidak adekuat; atau pada hal teknis yang lain seperti kegagalan berkomunikasi, kegagalan alat atau system yang lain. Dalam hal ini, untuk mencegah terjadinya Adverse Event salah satunya adalah diperlukannya peran dari anggota keluarga pasien, sehingga dapat meningkatkan keselamatan pasien di Rumah Sakit . 


\section{METODE}

Metode yang digunakan adalah metode kualitatif. Metode kualitatif adalah metode riset yang sifatnya memberikan penjelasan dengan menggunakan analisis. Menurut Sugiyono (2011), metode penelitian kualitatif adalah metode penelitian yang berlandaskan pada filsafat post positivisme, digunakan untuk meneliti pada kondisi obyek yang alamiah, (sebagai lawannya eksperimen) dimana peneliti adalah sebagai instrumen kunci, pengambilan sampel sumber data dilakukan secara purposive dan snowball, teknik pengumpulan dengan tri-anggulasi (gabungan), analisis data bersifat induktif atau kualitatif, dan hasil penelitian kualitatif lebih menekankan makna dari pada generalisasi

\section{HASIL}

Keluarga merupakan unit paling dekat dengan pasien, dan merupakan perawat utama bagi pasien. Keluarga berperan dalam menentukan cara atau perawatan yang diperlukan pasien di rumah sakit. Adverse Event atau Kejadian Tidak Diharapkan (KTD) merupakan suatu kejadian yang mengakibatkan cedera yang tidak diharapkan pada pasien karena suatu tindakan (commission) atau tidak mengambil tindakan yang seharusnya diambil (omission), dan bukan karena "underlying disease" atau kondisi pasien. Rumah Sakit dalam upaya memberikan pelayanan kesehatan melibatkan tim kerja dari berbagai profesi, maka rumah sakit menyiapkan sistem layanan terintegrasi yang berfokus pada pasien untuk memberi pelayanan yang aman.dengan enam sasaran keselamatan pasien yaitu :

1. Ketepatan identifikasi pasien

2. Komunikasi efektif

3. Pemberian obat secara aman

4. Ketepatan pasien, lokasi dan prosedur operasi

5. Pencegahan infeksi

6. Pencegahan pasien jatuh.

Dalam melaksanakan program tersebut diperlukan kerja sama antara tim kesehatan serta pasien dan keluarga. Peran keluarga secara aktif dalam menjaga keselamatan pasien rawat inap adalah

1. Memberikan informasi yang benar, jelas, lengkap dan jujur

2. Mengetahui dan melaksanakan kewajiban serta tanggung jawab pasien maupun keluarga. 
3. Mengajukan pertanyaan-pertanyaan untuk hal yang tidak dimengerti.

4. Memahami dan menerima konsekuensi pelayanan.

5. Mematuhi dan menghormati peraturan rumah sakit.

6. Memperlihatkan sikap menghormati dan tenggang rasa dalam proses bersama tim kesehatan mengelola pasien

7. Memenuhi kewajiban finansial yang disepakati.

\section{PEMBAHASAN}

Keluarga merupakan unit paling dekat dengan pasien, dan merupakan perawat utama bagi pasien. Keluarga berperan dalam menentukan cara atau perawatan yang diperlukan pasien di rumah sakit. Keberhasilan perawat di rumah sakit akan sia-sia jika tidak diteruskan di rumah yang kemudian mengakibatkan pasien harus dirawat kembali (kambuh). Peran serta keluarga sejak awal perawatan di rumah sakit akan meningkatkan kemampuan keluarga merawat pasien di rumah sehingga memungkinkan pasien tidak kambuh atau dapat dicegah.

Sebuah survei yang dilakukan di rumah sakit Amerika Serikat mengenai praktek pasien dan keterlibatan pasien dan keluarga pasien dalam mengelola pasien di rumah sakit menunjukkan hal yang luar biasa. Hasilnya pasien dan keluarga pasien yang dilibatkan dalam pengambilan keputusan secara bersama-sama dalam perawatan dan menjadikan pasien sebagai mitra dapat meningkatkan optimalisasi kesembuhan pasien, selain itu dengan melibatkan anggota keluarga seperti berpartisipasi dalam koordinasi keperawatan sangat penting. Keluarga merupakan bagian dari tim pengobatan dan perawatan. Apalagi di Indonesia dengan kultur sosialnya tinggi ditambah keterbatasan jumlah perawat di rumah sakit sehingga tugas merawat orang sakit yang dirawat di rumah sakit umumnya dilakukan oleh keluarga yang menjaga. Para anggota keluarga menunggui secara bergantian, bahkan sering menjaga bersama-sama. Sementara perawat di rumah sakit yang seharusnya merawat orang sakit juga harus melakukan tugas-tugas yang lain di bangsal perawatan. Maka, peran keluarga penting untuk memantau kebutuhan pasien dari laporan perawat atau jika perlu malakukan komunikasi langsung. Beberapa rumah sakit mengizinkan pasien untuk membawa alat komunikasi yang perlu digunakan. Hal ini juga terbukti dari hasil penelitian yang dilakukan di rumah sakit Amerika serikat bahwa dengan keterlibatan pasien maupun anggota keluarganya dalam merawat dan memberikan kesempatan kepada keluarga pasien untuk berkunjung ke rumah sakit lebih lama dapat menguragi resiko kecemasan yang berlebihan yang diderita oleh pasien. Tentunya hal ini dapat dirasakan jika penderita merasakan adanya 
dukungan sosial dari orang-orang sekitarnya, merasa dirinya dihargai, diperhatikan dan dicintai.

Adverse Event atau Kejadian Tidak Diharapkan (KTD) merupakan suatu kejadian yang mengakibatkan cedera yang tidak diharapkan pada pasien karena suatu tindakan (commission) atau tidak mengambil tindakan yang seharusnya diambil (omission), dan bukan karena "underlying disease" atau kondisi pasien. Kesalahan tersebut bisa terjadi dalam tahap diagnostic seperti kesalahan atau keterlambatan diagnose, tidak menerapkan pemeriksaan yang sesuai, menggunakan cara pemeriksaan yang sudah tidak dipakai atau tidak bertindak atas hasil pemeriksaan atau observasi; tahap pengobatan seperti kesalahan pada prosedur pengobatan, pelaksanaan terapi, metode penggunaan obat, dan keterlambatan merespon hasil pemeriksaan asuhan yang tidak layak; tahap preventive seperti tidak memberikan terapi provilaktik serta monitor dan follow up yang tidak adekuat; atau pada hal teknis yang lain seperti kegagalan berkomunikasi, kegagalan alat atau system yang lain.

Di Indonesia, telah dikeluarkan Kepmen nomor 496/Menkes/SK/IV/2005 tentang Pedoman Audit Medis di Rumah Sakit, yang tujuan utamanya adalah untuk tercapainya pelayanan medis prima di rumah sakit yang jauh dari medical error dan memberikan keselamatan bagi pasien. Perkembangan ini diikuti oleh Perhimpunan Rumah Sakit Seluruh Indonesia (PERSI) yang berinisiatif melakukan pertemuan dan mengajak semua stakeholder rumah sakit untuk lebih memperhatian keselamatan pasien di rumah sakit. Mempertimbangkan betapa pentingnya misi rumah sakit untuk mampu memberikan pelayanan kesehatan yang terbaik terhadap pasien mengharuskan rumah sakit untuk berusaha mengurangi medical error sebagai bagian dari penghargaannya terhadap kemanusiaan, maka dikembangkan system Patient Safety yang dirancang mampu menjawab permasalahan yang ada.

Pasien yang dirawat di rumah sakit merupakan individu yang sedang memiliki masalah kesehatan, sehingga dimungkinkan mengalami kesulitan memenuhi kebutuhan pribadi termasuk menjaga keselamatan sendiri, oleh sebab itu pasien membutuhkan dukungan dari keluarga dan tim kesehatan yang merawat. Rumah Sakit dalam upaya memberikan pelayanan kesehatan melibatkan tim kerja dari berbagai profesi, maka rumah sakit menyiapkan sistem layanan terintegrasi yang berfokus pada pasien untuk memberi pelayanan yang aman.dengan enam sasaran keselamatan pasien yaitu :

\section{Ketepatan Identifikasi Pasien}


Pasien dalam keadaan tidak sadar, gelisah, mengalami gangguan penglihatan, gangguan pendengaran, gangguan proses pikir, mendapat obat bius, atau gangguan lain tidak mampu melakukan identifikasi diri dengan benar selain itu pasien yang pindah ruang rawat atau bertukar tempat tidur saat perawatan di rumah sakit berisiko mengalami ketidaktepatan identifikasi, maka rumah sakit menyusun sistem untuk memastikan identifikasi pasien sebagai individu yang akan menerima pelayanan adalah tepat dan jenis pelayanan atau pengobatan terhadap individu tersebut adalah sesuai. Peran Pasien dan keluarga untuk memastikan ketepatan identifikasi pasien adalah: Memberikan data diri yang tepat pada saat mendaftar sesuai dokumen data diri yang dimiliki. Data utama yang diperlukan adalah nama dan tanggal lahir Selama rawat inap pasien dipakaikan gelang. Pasien dan keluarga harus memahami fungsi gelang dan patuh menggunakan gelang tersebut selama rawat inap karena gelang tersebut dipakai oleh tim kesehatan guna memastikan kebenaran identitas dan faktor risiko pasien saat memberikan pelayanan.

- Gelang warna biru untuk laki-laki dan gelang warna merah muda untuk perempuan dipakai untuk identifikasi

- Gelang warna merah dipasangkan pada pasien yang memiliki riwayat alergi

- Gelang warna kuning dipasangkan pada pasien yang memiliki risiko jatuh

Pasien atau keluarga kooperatif saat dilakukan verifikasi identitas oleh petugas saat akan melakukan tindakan, memberikan obat, mengambil preparat untuk pemeriksaan laborat dan lain-lain.

\section{Komunikasi efektif}

Pasien yang menjalani rawat inap dikelola oleh dokter dan berbagai profesi lain sebagai tim dengan menerapkan sistem komunikasi yang efektif untuk memberikan pelayanan Peran pasien dan keluarga mewujudkan komunikasi efektif adalah:

- Menunjuk atau menetapkan anggota keluarga yang diberi kewenangan untuk berkomunikasi dengan tim kesehatan. Penunjukkan ini diperlukan untuk memastikan komunikasi berlangsung efektif dan berkesinambungan, tidak mengalami rantai komunikasi yang panjang dan kompleks yang berisiko menyebabkan perubahan makna isi informasi.

- Memberikan informasi dan data terkait kondisi pasien kepada tim kesehatan dengan benar dan jelas.

- Memberikan informasi pada petugas bila ada kejadian tidak diharapkan. 
- Meminta informasi yang diperlukan kepada tim kesehatan

3. Pemberian obat secara aman

Pemberian obat merupakan bagian yang mengambil porsi dominan dalam tata kelola pasien rawat inap. Peran serta keluarga dalam menjamin keamanan pemberian obat adalah:

- Memberikan informasi yang lengkap tentang riwayat obat yang pernah dipergunakan sebelum masuk rumah sakit

- Memberikan informasi tentang riwayat alergi atau reaksi yang dialami saat menggunakan obat tertentu

- Mendukung pengawasan pemberian obat selama rawat inap dengan cara memastikan identitas pasien benar, menanyakan jenis obat yang diberikan, tujuan pemberian, dosis dan waktu pemberian obat

4. Kepastian Tepat-Lokasi, Tepat-Prosedur, Tepat-Pasien Operasi

Tindakan operasi merupakan salah satu prosedur yang mungkin dilakukan pada pasien untuk mengatasi masalah kesehatannya. Bagian tubuh yang akan dioperasi bisa meliputi bagian yang bersisi (misalnya tangan atau kaki kanan dan kiri, mata kanan dan kiri) atau bagian yang multipel level (misalnya tulang belakang) atau bagian yang multipel struktur (misalnya jari tangan) dengan demikian diterapkan sistem untuk memastikan tindakan tepat-lokasi, tepat-prosedur, tepat-pasien. Salah satu prosedur yang dilakukan sebelum tindakan operasi adalah proses verifikasi. Peran pasien dan keluarga dalam proses verifikasi praoperasi adalah memberikan informasi yang benar dan bekerja sama secara kooperatif Proses yang dilakukan meliputi

- Verifikasi lokasi, prosedur, dan pasien yang benar

Proses ini dilakukan dengan membuat tanda pada lokasi yang dioperasi.

Penandaan lokasi operasi ini melibatkan pasien, dibuat oleh dokter yang akan melakukan tindakan dan dilaksanakan saat pasien dalam keadaan sadar .Tanda ini tidak boleh dihapus dan harus terlihat sampai saat akan disayat.

- Memastikan bahwa semua dokumen, foto (imaging), hasil pemeriksaan yang relevan tersedia, diberi label dengan baik

- Melakukan verifikasi ketersediaan peralatan khusus yang dibutuhkan.

5. Pengurangan risiko infeksi terkait pelayanan kesehatan

Rumah sakit merupakan tempat yang memungkinkan berkumpulnya berbagai jenis kuman sedangkan pasien yang sedang dirawat memiliki daya tahan tubuh relatif rendah dengan demikian diperlukan suatu proses bersama untuk mencegah timbulnya 
infeksi lain yang tidak berhubungan dengan penyakit utama pasien. Peran pasien dan keluarga dalam pengurangan risiko terkait pelayanan kesehatan adalah:

- Menerapkan prosedur cuci tangan yang benar

Keluarga memiliki kemungkinan sering kontak dengan pasien, maka untuk melindungi diri sendiri dan melindungi pasien dari perpindahan kuman disarankan keluarga menerapkan prosedur cuci tangan yang benar pada 5 (lima) momen yaitu saat sebelum kontak dengan pasien, sesudah kontak pasien, sesudah ke toilet, sebelum dan sesudah makan. Perlu diperhatikan juga bahwa lingkungan sekitar pasien berisiko terpapar kuman maka disarankan mencuci tangan sesudah kontak dengan lingkungan pasien (meja, alat tenun, tempat tidur dsb), Guna memperoleh hasil cuci tangan yang optimal Pasien dan keluarga disarankan mencermati dan mengikuti petunjuk 6 (enam) langkah mencuci tangan yang diberikan oleh petugas atau panduan cuci tangan yang ada di rumahsakit

- Membatasi pengunjung pasien

Selama pasien dirawat di rumah sakit seyogyanya pasien tidak berinteraksi dengan banyak orang karena berisiko terpapar kuman dari pengunjung dalam keadaan pertahanan diri yang relatif rendah dengan demikian peran keluarga diperlukan untuk membatasi pengunjung yang kontak dengan pasien

- Menerapkan etika batuk yang benar

Keluarga dan pengunjung yang batuk berisiko menyebarkan kuman melalui partikel halus di udara dengan demikian bila sedang mengalami batuk keluarga perlu menggunakan masker atau menerapkan tehnik perlindungan yang benar saat batuk yaitu menutup mulut dan hidung menggunakan lengan.

6. Pengurangan Risiko Pasien Jatuh

Individu yang sedang sakit memiliki keterbatasan dalam pengamanan diri termasuk menghindari jatuh. Rumah sakit mengambil tindakan untuk mengurangi risiko dengan melakukan pengkajian faktor-faktor yang dapat menyebabkan jatuh seperti, penggunaan obat, gaya jalan dan keseimbangan, alat bantu berjalan yang digunakan oleh pasien, riwayat jatuh saat berjalan atau saat istirahat baring di tempat tidur. Peran pasien dan keluarga dalam mencegah jatuh saat dirawat di rumah sakit adalah:

- Pastikan penanda pasien beresiko jatuh berupa gelang kuning dipakai pasien Jangan melepas atau memindah kartu kuning yang dipasang petugas dekat tempat tidur pasien atau di depan kamar pasien karena kartu tersebut merupakan penanda untuk mewaspadai pasien yang beresiko jatuh 
- Keluarga atau pasien perlu memastikan diri untuk memahami informasi yang diberikan oleh petugas agar dapat mendukung tindakan pencegahan jatuh. Informasi yang perlu diketahui adalah:

- faktor resiko jatuh yang teridentifikasi seperti obat yang dipergunakan, kesadaran pasien, keseimbangan saat berjalan,dll

- tindakan pencegahan jatuh yang perlu dilakukan

- cara untuk minta bantuan

- cara menggunakan bel atau sarana komunikasi di ruangan

- cara mengatur pengamanan tempat tidur

- pengggunaan tali pengaman, dll

Dalam melaksanakan program tersebut diperlukan kerja sama antara tim kesehatan serta pasien dan keluarga. Peran keluarga secara aktif dalam menjaga keselamatan pasien, yaitu:

1. Memberikan informasi yang benar, jelas, lengkap dan jujur

2. Mengetahui dan melaksanakan kewajiban serta tanggung jawab pasien maupun keluarga.

3. Mengajukan pertanyaan-pertanyaan untuk hal yang tidak dimengerti.

4. Memahami dan menerima konsekuensi pelayanan.

5. Mematuhi dan menghormati peraturan rumah sakit.

6. Memperlihatkan sikap menghormati dan tenggang rasa dalam proses bersama tim kesehatan mengelola pasien

7. Memenuhi kewajiban finansial yang disepakati.

\section{PENUTUP}

Keselamatan pasien merupakan salah satu indikator mutu pelayanan dari suatu unit atau rumah sakit. Bila keselamatan pasien kurang diperhatikan sehingga menyebabkan kejadian tidak diinginkan dan merugikan pasien (adverse event) maka reputasi mutu institusi (dalam hal ini rumah sakit) di mata masyarakat akan "turun". Dalam hal ini, untuk mencegah terjadinya Adverse Event salah satunya adalah diperlukannya peran dari anggota keluarga pasien, sehingga dapat meningkatkan keselamatan pasien di Rumah Sakit . Keluarga berperan dalam menentukan cara atau perawatan yang diperlukan pasien di rumah sakit. Peran keluarga dalam perawatan pasien di rumah sakit sangat penting dan dibutuhkan oleh tenaga medis lainnya untuk membuat pasien cepat pulih. 


\section{DAFTAR PUSTAKA}

Fitriana, Y. ( 2018). Pelaksanaan Patient Safety di Rumah Sakit Umum Daerah dan Rumah Sakit Umum Swasta Bantul Berdasarkan Ketentuan Undang - Undang Nomor 44 Tahun 2009 Tentang Rumah Sakit. Jurnal Kebidanan. 7 (1), 28-39. Doi: 10.26714/jk.7.1.2018.28-39

Herawati, Y., T. (2015). Budaya Keselamatan Pasien di Ruang Rawat Inap Rumah Sakit X Kabupaten Jember. Jurnal Ikatan Kesehatan Masyarakat. 11(1), 54-58

Hermawan, I. (2019). Metodologi Penelitian Pendidikan Kuantitatif, Kualitatif, dan Mixed Methode. Kuningan: Hidayatul Quran

Herrin J. et al., Patient and Family Engagement: A Survey of US Hospital Practices. BMJ Qual Saf 2015;0:1-8. doi:10.1136/bmjqs-2015-004006.

Ismainar, H. (2019). Keselamatan Pasien di Rumah Sakit. Yogyakarta: Deepublish.

Najihah. (2018). Budaya Keselamatan Pasien dan Insiden Keselamatan Pasien Di Rumah Sakit: Literature Review. Journal Of Islamic Nursing. 3 (1), 1-4

Priyoto, Widyastuti. (2014). Kebutuhan Dasar Keselamatan Pasien. Graha Ilmu: Yogyakarta Rivai, F.,dkk. (2016). Faktor Yang Berhubungan Dengan Implementasi Keselamatan Pasien Di Rsud Ajjappannge Soppeng Tahun 2015. Jurnal Kebijakan Kesehatan Indonesia . 5(4). 155-156

Selleya C.B., Sinolungan, dan Hamel. (2013). Hubungan Pengetahuan dan Sikap perawat Dengan pelaksanaan Keselamatan Pasien (Patient Safety) di Ruang Rawat Inap RSUD Liun Kendade Tahun. Jurnal keperawatan. Volume 1. https://ejournal.unsrat.ac.id/index.php/jkp/article/view/2237.

Simamora, R. H. (2019). Buku ajar pelaksanaan identifikasi pasien. Uwais Inspirasi Indonesia.

Tutiany, Lindawati, Paula Krisanti. (2017). Manajemen Keselamatan Pasien. Jakarta: Kementrian Kesehatan Republik Indonesia. 